\title{
Banana Peel Cellulose Nanofibers (CNFs) as Retrofitting Material to Soy- Protein in Manufacturing Biodegradable Food Packaging
}

\author{
Vandon T. Borela ${ }^{1}$, Dhian Ashley DS. Apolinar ${ }^{2}$ \\ ${ }^{1}$ Teacher, Parang High School, the Philippines \\ ${ }^{2}$ Teacher, Parang High School, the Philippines
}

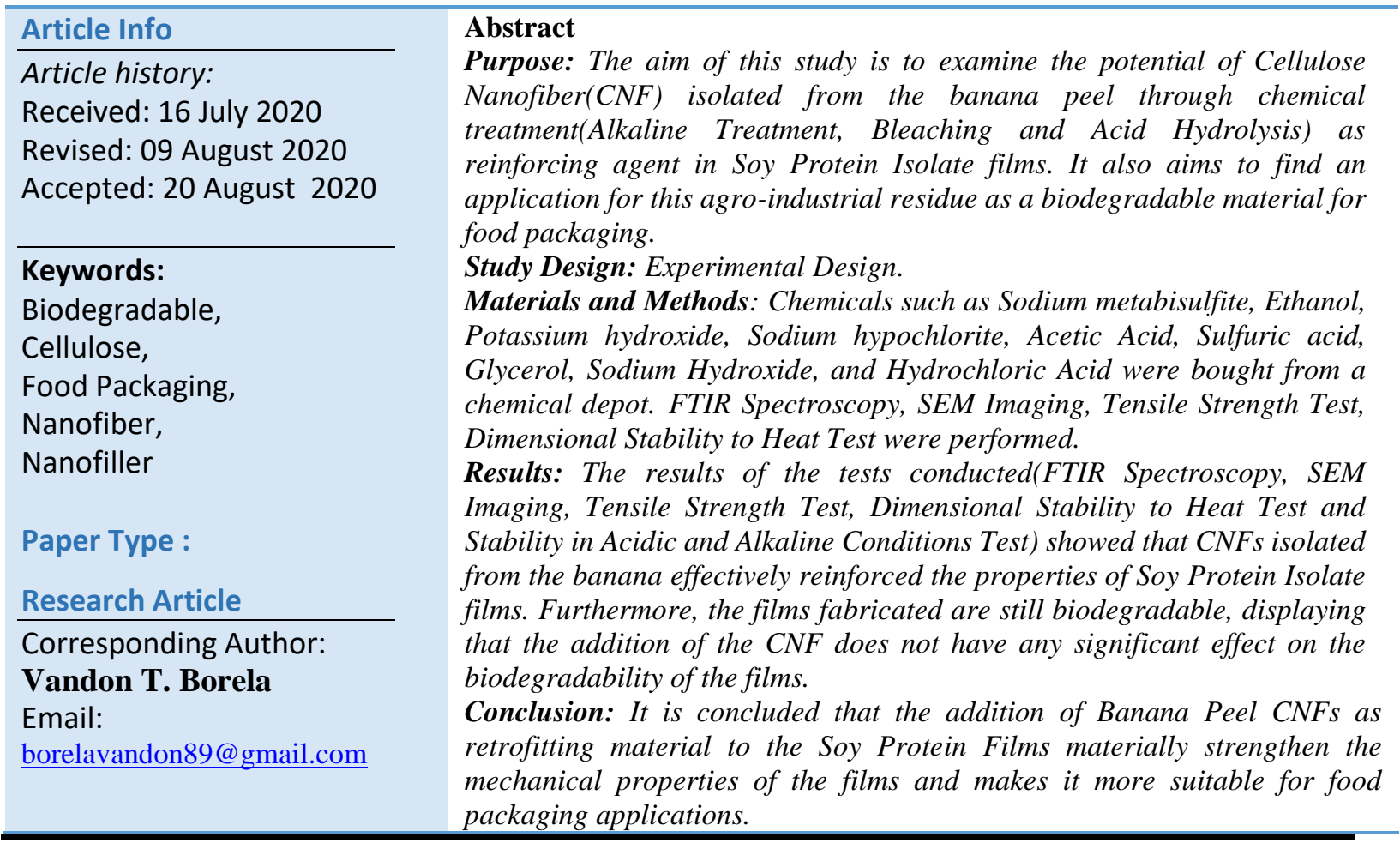

\section{Introduction}

The world is now facing environmental problems caused by non-biodegradable plastic packaging materials as well as the consumer's demand for high-quality food products. Due to all this, the interest in creating biodegradable plastic grew considerably. However, these bioproducts need reinforcing materials such as cellulose nanofibers to match with the mechanical and barrier properties of petrochemical-based plastics.

Packaging performs a series of disparate tasks: it protects contents from contamination and spoilage, makes it easier to transport and store goods and provides uniform measures of contents (Robertson, 2016). With the new consumer demands and increasing population, it is important to create packaging materials that will cater to the needs of consumers. Food packaging has been impacted by notable changes in food distribution, including globalization of the food supply, consumer trends for more fresh and convenient foods as well as a desire for safer and better-quality foods (Khan et al., 2014). 
Plastic was the most used material for food packaging. Plastic packaging for food and non-food applications is non-biodegradable, and uses up valuable and scarce non-renewable resources like petroleum(Tang et al., 2012). Concerns on environmental waste problems caused by non-biodegradable petrochemical-based plastic packaging materials as well as the consumer's demand for high-quality food products has caused an increasing interest in developing biodegradable packaging materials using annually renewable natural biopolymers such as polysaccharides and proteins(Rhim \& Perry, 2007). In addition, these renewable materials also exhibit properties such as biodegradability, biocompatibility, low toxicity, and low cost among others (Mecking, 2004). However, to replace petroleum-based thermoplastics, biopolymers need to have comparable properties and processing methods to those conventionally used (Peterrson, 2009). These can be achieved by adding reinforcing materials such as nanocellulose.

Soy protein is the protein that is found in soybeans. Soy protein isolate (SPI) is a highly purified form of soy protein made up of $90 \%$ protein on a moisture-free basis. SPI may be used to prepare edible and biodegradable packaging films (Kokoszka et al., 2010). In a study conducted by Sharma, S., \& Luzinov (2013), it is demonstrated that bioplastics from protein feedstock have advantages over traditional plastics, especially in areas such as packaging. While in the study of Guo, Gaiping and his team (2015), Soy protein acting as filler exhibited reinforcing effect on PBAT matrix. The tensile strength and elongation at break of SPI/PBAT blends were modeled. The blends with as high as $28.6 \mathrm{wt} \%$ SPI still possessed a good ductility. Soy protein was easily degraded in the soil and thus made the blends biodegradable as a whole. In addition, soy protein films possess high potential for application as food packaging films, but organic and inorganic fillers can be added into SPI matrix to improve the properties (Koshy et al., 2015).

One possible filler is nanocellulose. Cellulose, the most abundant polymer on Earth, is renewable, biodegradable, as well as non-toxic. Purification of cellulose from plant fibers involves chemical treatments consisting of alkali extraction and bleaching (Dufresne, 2013). It is often being regarded as the next generation renewable reinforcement for the production of high-performance bio composites (Lee et al., 2014). The development of nanocellulose and nanocellulose-based composites and materials has attracted significant interest in recent decades because they show unique and potentially useful features, including abundance, renewability, high strength and stiffness, eco-friendliness, and low weight (Kargarzadeh et al. 2017). In a research study done by Cho \& Park (2011) nanocellulose-reinforced PVA nanocomposite films were prepared by the casting method with different nanocellulose loadings, which were exposed to tensile test, thermogravimetric analysis (TGA) and dynamic mechanical analysis (DMA). The results indicate that the nanocellulose has a great potential to reinforce PVA polymers. Moreover, Boufi et al. (2014) examined the dynamic mechanical properties of the nanocomposites, and the rubbery modulus was found to depend mainly on the aspect ratio of the cellulosic nanoparticles. Higher aspect ratio resulted in higher reinforcing capability.

Some of the materials already used in reinforcing different polymer matricesare as follows: wood, cotton, rice straw, rice husk, hemp, pineapple leaf, and bamboo(Majeed et al., 2013). Some non-biodegradable polymers that can be used are polyethylene (PE) and ISSN: 2709-0159(Print)

Copyright (c) 2020, Journal of Scientific Research in Medical and Biological Sciences (JSRMBS), Under the license CC BY- 4.0 
polypropylene. In addition, biodegradable polymers to be used are poly lactic acid (PLA), polyvinyl alcohol (PVOH), starch, polycaprolactone (PCL), methylcellulose, and chitosan. For nanocellulose fiber-based composites, aspect ratio of fibers, geometric andmechanical percolation effects are the main contributors to the resulting properties (De Azeredo, 2009).

Purification of cellulose from plant fibers involves chemical treatments consisting of alkali extraction and bleaching; nanoparticles can be extracted from this naturally occurring polymer using a top-down mechanically or chemically induced deconstructing strategy (Koshy, 2015). Moran et al. (2008) conducted a study investigating the feasibility of extracting cellulose from sisal fiber by means of two different procedures. These processes included usual chemical procedures such as acid hydrolysis, chlorination, alkaline extraction, and bleaching. The final products were characterized by means of Thermogravimetric Analysis (TGA), Infrared Spectroscopy (FTIR), X-Ray Diffraction (XRD), Differential Scanning Calorimetry (DSC) and Scanning Electronic Microscopy (SEM).

One possible source of cellulose nanofibers is the peel of a Banana. Banana is one of the most popular fruits and its cultivation is widespread in most tropical countries (de Morais et al., 2011). The process of banana cultivation and industrialization produces a considerable amount of cellulose-rich residues, and the use of this biomass could help reduce environmental pollution and add value to the cellulose byproduct. In this sense, the research about involving this fruit and seeking sustainable development has been encouraged. The banana peel is a potential source of cellulosic fiber, a material that is essential to produce paper and clothing and which has recently found applications in the production of nanomaterials (Elanthikkal et al., 2010).

This aim of this research study is to investigate the potential of CNFs isolated from the banana peel as reinforcing agent in Soy Protein Isolate films and to find whether this agroindustrial residue as a biodegradable material can be applied in food packaging. This study is limited to determining the potential of CNFs isolated from the banana peel as reinforcing agent in Soy Protein Isolate films. Mechanical properties of the films was tested in a way that is partly the same with Labonete, G. (2015), to ensure that it can be used in food packaging, tests like FT-IR Analysis, SEM Imaging, Tensile Strength Test, Dimensional Stability to Heat Test and Stability in Acidic and Alkaline Conditions Test were conducted. Biodegradability was tested in the ways recommended by Lori Rosario et. al.(2010) in terms of biodegradability using of $\mathrm{CO}_{2}$.

\section{Methodology and Procedures}

\section{The Research Design}

The method of this research study is experimental. It is a causal research design where the effect caused by the independent variable on the dependent variable is observed and determined. The term experimental design refers to a plan for assigning experimental units to a treatment condition.

\section{Gathering of Materials}


Chemicals such as Sodium metabisulfite, Ethanol, Potassium hydroxide, Sodium hypochlorite, Acetic Acid, Sulfuric acid, Glycerol, Sodium Hydroxide, and Hydrochloric Acid were bought from a chemical depot as indicated in (Table 1). Laboratory equipment like centrifuge, magnetic stirrer, hot plate, analytical balance, etc. were prepared.

Table 1: Chemicals Needed

\begin{tabular}{|c|c|c|}
\hline Chemicals & Amount Needed & $\begin{array}{c}\text { Actual Amount } \\
\text { Needed }\end{array}$ \\
\hline $\begin{array}{c}\text { Sodium } \\
\text { metabisulfite }\end{array}$ & $1 \% \mathrm{w} / \mathrm{v}$ or $1 \mathrm{~g}$ per $100 \mathrm{~mL}$ & $20 \mathrm{~g}$ \\
\hline Ethanol & & $250 \mathrm{~mL}$ \\
\hline $\begin{array}{l}\text { Potassium } \\
\text { hydroxide }\end{array}$ & $5 \% \mathrm{w} / \mathrm{v}$ or $5 \mathrm{~g}$ per $100 \mathrm{~mL}$ & $25 \mathrm{~g}$ \\
\hline $\begin{array}{c}\text { Sodium } \\
\text { hypochlorite }\end{array}$ & $2 \% \mathrm{w} / \mathrm{v}$ or $2 \mathrm{~mL}$ per $100 \mathrm{~mL}\left(1^{\mathrm{st}}, 2^{\text {nd }}\right.$ and $3^{\text {rd }}$ treatment $)$ & $15 \mathrm{~mL}$ for $750 \mathrm{~g}$ \\
\hline Acetic Acid & $10 \% \mathrm{v} / \mathrm{v}$ or $20 \mathrm{~mL}$ per $100 \mathrm{~mL}\left(1^{\text {st }} \& 2^{\text {nd }}\right.$ treatment $)$ & $10 \mathrm{~mL}$ \\
\hline Sulfuric acid & $1 \% \mathrm{v} / \mathrm{v}$ or $1 \mathrm{~mL}$ per $100 \mathrm{~mL}$ & $50 \mathrm{~mL}$ \\
\hline Glycerol & $50 \%$ wt or $2.5 \mathrm{~mL}$ per $5 \mathrm{~g}$ of SPI(per films) & $1.25 \mathrm{~mL}$ \\
\hline $\begin{array}{l}\text { Sodium } \\
\text { Hydroxide }\end{array}$ & $\begin{array}{c}1 \mathrm{M} \text { or } 40 \mathrm{~g} \text { per 1Litter and } \\
0.1 \mathrm{M} \text { or } 4 \mathrm{~g} \text { per } 1 \text { Litter(For Acidity and Alkalinity Test) }\end{array}$ & $60 \mathrm{~g}$ \\
\hline $\begin{array}{l}\text { Hydrochloric } \\
\text { Acid }\end{array}$ & $0.1 \mathrm{M}$ or 3.7 per 1 Litter(For Acidity and Alkalinity Test) & $18.5 \mathrm{~g}$ \\
\hline
\end{tabular}

Source: Authors

Concentration of a solution can be expressed in terms of percentage composition. It is based on the weight or volume of the components of solution.

- Weight / Weight \%

$1 \% \mathrm{w} / \mathrm{w}$ or wt solution means 1 gram of solute is dissolved in 100 grams of solution.

- Weight / volume \%

$1 \% \mathrm{w} / \mathrm{v}$ solution means 1 gram of solute is dissolved in $100 \mathrm{ml}$ of solution.

- Volume / volume \%

$1 \% \mathrm{v} / \mathrm{v}$ solution means $1 \mathrm{ml}$ of solute is dissolved $100 \mathrm{ml}$ of solution.

- 1M Solution is equal to number of moles of solute / volume of solution in litre

$1 \mathrm{M} \mathrm{NaOH}=$ Molecular Mass is 40, then there are $40 \mathrm{~g}$ of $\mathrm{NaOH}$ per 1 litter

\section{Preparation of Banana Peel Bran}

Waste banana peels were collected from the neighbourhood (Banana Cue stores and from the School Canteen). The bran was prepared according to the method of H. Tibolla et. al. (2018). The banana peels were manually removed and immediately immersed in a $1 \% \mathrm{w} / \mathrm{v}$ potassium metabisulfite solution for 24 hours to inhibit oxidation. Next, they were arranged in aluminium trays and dried in an oven for 24 hours. The dried peels were then milled. The bran was washed and soaked with ethanol to remove lipid fractions, and dried again in an oven for 24 hours. The resulting material was sieved through mesh sieve, which afforded microparticles.

\section{Isolation of Cellulose Nanofiber from Banana Peel Bran}


CNFs were isolated from the banana peel by using the chemical treatment adapted from the study of H. Tibolla et al. (2018), which eliminated non-cellulosic components such as pectin, hemicelluloses, and lignin. First, the bran was treated with $5 \% \mathrm{w} / \mathrm{v} \mathrm{KOH}$ solution under magnetic stirring at room temperature for 14 hours, which solubilised the pectin and the hemicelluloses. The insoluble residue was stirred and treated with $1 \% \mathrm{v} / \mathrm{v} \mathrm{NaOCl} 1 \mathrm{~h}$. The bleaching treatment broke down the phenolic compounds or molecules displaying chromophoric groups in the lignin; it also removed the byproducts of such breakdown, whitening the pulp. The residue was submitted to 2 more bleaching processes using the same procedure to ensure effective discoloration. Finally, the insoluble residue was subjected to a synthetic acid hydrolysis using $\mathrm{H} 2 \mathrm{SO} 4$ solution in a reflux set up. The solution was stirred for 1 hour with $10 \% \mathrm{v} / \mathrm{v}$ solution of $\mathrm{H} 2 \mathrm{SO} 4$. It was then subjected to heat at $80^{\circ} \mathrm{C}$ for 2 hours to remove mineral traces and to hydrolyze amorphous cellulose, providing the required nanofibers. The product was put into centrifugation to obtain the insoluble residue. After each step of the chemical treatment, the insoluble residue was obtained through centrifugation. The final residue was diluted with distilled water, and the suspension is stored at $4^{\circ} \mathrm{C}$ in a sealed container.

\section{Creation of Cellulose Nanofiber reinforced Soy Protein Isolate Film}

The number of films to be fabricated is listed in Table (2). The fabrication was done in a modified version of the method by Labonete, G. (2015).

Table 2: Number of Films to be Fabricated

\begin{tabular}{|c|c|c|c|c|c|c|c|}
\hline \multirow{2}{*}{$\begin{array}{l}\text { Film } \\
\text { CNF } \\
\text { Loadi } \\
\text { ngs } \\
\end{array}$} & \multicolumn{6}{|c|}{ Number of Films needed for Tests } & \multirow{2}{*}{$\begin{array}{l}\text { Films } \\
\text { needed } \\
\text { per } \\
\text { Loading }\end{array}$} \\
\hline & $\begin{array}{l}\text { FT- } \\
\text { IR }\end{array}$ & \begin{tabular}{|l} 
SEM \\
Analysis
\end{tabular} & \begin{tabular}{|l} 
Tensile \\
Test
\end{tabular} & $\begin{array}{ll}\text { Stability in } \\
\text { Acid \& } \\
\text { Alkaline }\end{array}$ & $\begin{array}{l}\text { Dimensional } \\
\text { Stability to Heat }\end{array}$ & $\begin{array}{l}\text { Biodegra } \\
\text { dability } \\
\text { Test }\end{array}$ & \\
\hline $0.0 \mathrm{~mL}$ & 1 & $\begin{array}{l}\text { The same } \\
\text { film used } \\
\text { in } \\
\text { FTIR }\end{array}$ & $\begin{array}{l}1 \text { film of } \\
6 \text { by } 1.5 \\
\text { inches }\end{array}$ & 1 & 1 & 1 & 3 \\
\hline $0.5 \mathrm{~mL}$ & 1 & $\begin{array}{l}\text { The same } \\
\text { film used } \\
\text { in FTIR }\end{array}$ & \begin{tabular}{|l|}
1 film of \\
6 by 1.5 \\
inches
\end{tabular} & 1 & 1 & 1 & 3 \\
\hline $1.0 \mathrm{~mL}$ & 1 & $\begin{array}{l}\text { The same } \\
\text { film used } \\
\text { in FTIR }\end{array}$ & $\begin{array}{l}1 \text { film of } \\
6 \text { by } 1.5 \\
\text { inches }\end{array}$ & 1 & 1 & 1 & 3 \\
\hline Total I & be & Films To & Fabrica & & & & 9 \\
\hline
\end{tabular}

Source: Authors

For all films, $50 \mathrm{wt} \%$ of glycerol was added with respect to the amount of SPI. In a 250$\mathrm{ml}$ conical flask, $1.5 \mathrm{~g}$ of SPI and $15 \mathrm{~mL}$ distilled water was mixed using a magnetic stirrer for ten minutes at room temperature. Then, $50 \mathrm{wt} \%$ glycerol with respect to SPI and corresponding CNF content $(0.0 \mathrm{~mL}, 0.5 \mathrm{~mL}$ and $1 \mathrm{~mL}$ in with due respect to SPI) was added to the mixture. The solution was stirred for ten minutes at room temperature. The $\mathrm{pH}$ of the solution was 
adjusted to alkaline using a freshly prepared $1 \mathrm{M} \mathrm{NaOH}$ solution. The $\mathrm{pH}$ was measured using litmus paper. The solution was stirred again for ten minutes at room temperature. The solution was degassed using the process of low pressure-degassing described by Klawonn et al. (2015). The resulting solution was transferred to petri dishes and aluminium trays(for tensile test) and were dried in an oven for 7 hours at $55^{\circ} \mathrm{C}$ as initial temperature. The amount of SPI, glycerol and CNF used in preparing the films was summarized and listed in the table below.

Table 3: Amount of SPI, Glycerol and CNF per film

\begin{tabular}{|c|c|c|c|c|}
\hline Films & SPI(g) & Glycerol(mL) & CNF(mL) & Water(mL) \\
\hline 1 & 1.5 & 0.75 & $0.0 \mathrm{~mL}$ & 15 \\
\hline 2 & 1.5 & 0.75 & $0.5 \mathrm{~mL}$ & 15 \\
\hline 3 & 1.5 & 0.75 & $1.0 \mathrm{~mL}$ & 15 \\
\hline
\end{tabular}

Source: Authors

\section{Characterization of CNF reinforced Soy Protein Isolate Film}

Properties of the resulting films are described using the following tests:

\section{FT-IR Spectroscopy}

The functional groups present in the film were determined through an Attenuated Total Reflectance (ATR) accessory with 20 scans at the range of $4000-600 \mathrm{~cm}^{-1}$ using a Perkin Elmer FT-IR Spectrometer Frontier.

\section{FE-SEM Imaging}

FE-SEM imaging was used to produce complex, high magnification images of the film's surface topology/morphology. The imaging was done with a Dual Beam Helios Nanolab $600 \mathrm{i}$ with an accelerating voltage of $2.0 \mathrm{kV}$ and probe current of $86 \mathrm{pA}$.

\section{Tensile Strength Test}

Using an improvised manual tensile testing method, the tensile strength of the Films at break will be tested using $\mathrm{T}=\left(\mathrm{N} / \mathrm{m}^{\wedge} 2\right)$ where $\mathrm{T}$ is tensile strength, $\mathrm{N}$ is the stress or force applied and $\mathrm{m}$ is the expansion or the change in length .

\section{Dimensional Stability to Heat}

The dimensional stability to heat of the films was tested in an air oven at $80^{\circ} \mathrm{C}$ as initial temperature for 1 minute, 2 minutes and 3 minutes under a $200 \mathrm{~g}$ load. Initial length of film samples was $20.0 \mathrm{~mm}$. The dimensional stability was calculated by [(Initial length/Final Length)100] .

\section{Measure of Stability in acidic and alkaline solutions}

Swelling rate of the films immersed in $0.1 \mathrm{M} \mathrm{HCL}$ at room temperature was measured. Changes in physical appearance were observed after 5 days. In petri dishes, films with varying CNF content $(0 \mathrm{~mL}, 0.5 \mathrm{~mL} \& 1 \mathrm{~mL}$ in with due respect to SPI) were soaked in $0.1 \mathrm{M}$ HCI for 5 days. Photographs of the films are recorded at different time intervals: 5 mins and 5 days. The 
petri dishes were also occasionally shaken. A similar method was done for films soaked in 0.1 $\mathrm{M} \mathrm{NaOH}$.

\section{Biodegradability Test}

In plastic jars, $300 \mathrm{~g}$ of soil were put with $1 \mathrm{~g}$ of compost for every $25 \mathrm{~g}$ of soil. $12 \mathrm{~mL}$ of $0.5 \mathrm{M} \mathrm{KOH}$ Solution and $40 \mathrm{~mL}$ of distilled water were put into small glass containers and were placed inside the plastic jars. The jars were kept inside a cabinet for 8 days to inhibit $\mathrm{CO}_{2}$ Evolution that aided the biodegradation process. Photographs of the films inside the jar were recorded at different time intervals: 4 days and 8 Days.

\section{Results and Discussion}

Figure 1: FTIR Spectroscopy of the Film with 1mL CNF Loading

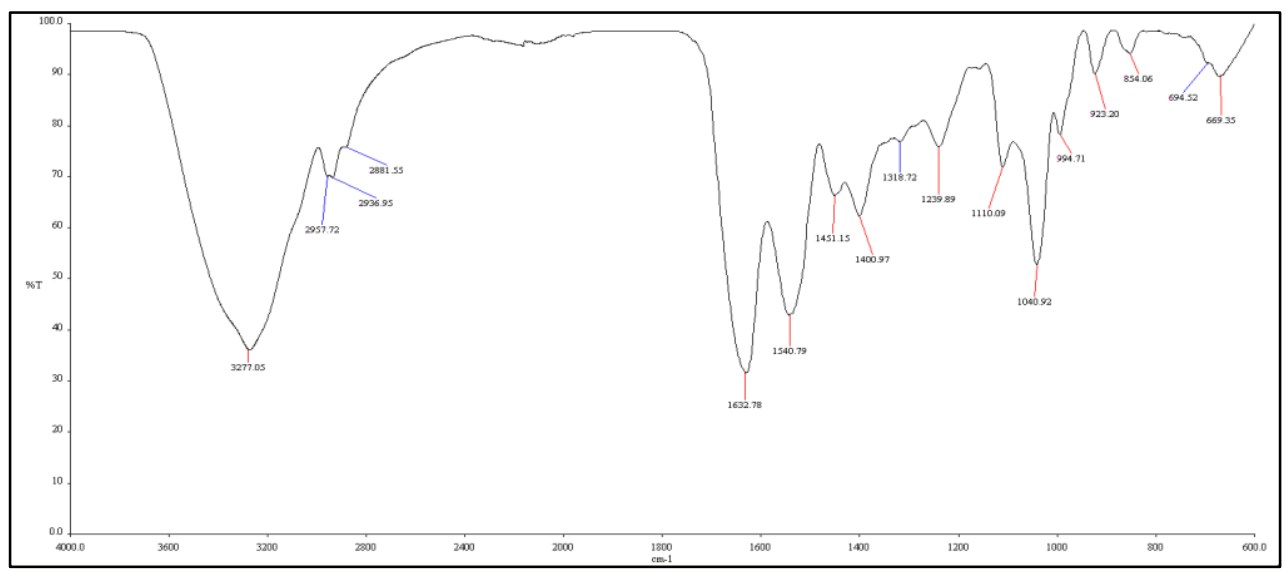

Figure 1: FTIR Spectroscopy of the Film with $1 m L$ CNF Loading

Figure 1 shows the FTIR Vibration Spectrum of the Film with 1.0mL CNF Loading. It suggests the presence of Protein.

Table 4: Peak assignments in the infrared spectrum of the Film with $1.0 \mathrm{~mL}$ CNF Loading

\begin{tabular}{|c|c|c|c|}
\hline $\begin{array}{c}\text { Protein, } \\
\text { Standard*+ }\end{array}$ & $\begin{array}{l}\text { Film with } 1 \mathrm{~mL} \\
\text { loading of } \mathrm{CNF}\end{array}$ & $\begin{array}{c}\text { Structure/ } \\
\text { Compound Type* }\end{array}$ & Bonds* \\
\hline 3290 & 3277.05 & Amine/Alcohol & $\mathrm{N}-\mathrm{H}$ Stretching/ \\
\hline 3077 & & \multirow{4}{*}{ Alkanes } & $-\mathrm{CH}_{2^{-}}$ntisymmetric \\
\hline 2955 & 2957.72 & & Stretching \\
\hline 2920 & 2936.95 & & \\
\hline 2861 & 2881.55 & & $\begin{array}{l}-\mathrm{CH}_{2}-\text { Symmetric } \\
\text { Stretching }\end{array}$ \\
\hline 1652 & 1632.78 & \multirow[t]{2}{*}{ Amide } & $\mathrm{C}=\mathrm{O}$ Stretching \\
\hline 1540 & 1540.79 & & $\mathrm{~N}-\mathrm{H}$ Combination \\
\hline 1453 & 1451.15 & Alkanes & $\mathrm{CH}_{2}$ Bending \\
\hline 1398 & 1400.97 & Primary Amine & $\mathrm{C}-\mathrm{NH}_{2}$ Bending \\
\hline 1310 & 1318.72 & & \\
\hline
\end{tabular}




\begin{tabular}{|c|c|c|c|}
\hline 1253 & 1239.89 & Amide & $\mathrm{C}-\mathrm{N}$ Stretching \\
\hline 1099 & 1110.09 & \multirow[t]{2}{*}{ Alcohol/Ester } & \multirow[t]{2}{*}{$\mathrm{C}-\mathrm{O}$ Bending } \\
\hline & $* * 1040.92$ & & \\
\hline & $* * 994.71$ & \multirow{5}{*}{ Alkanes } & \multirow{5}{*}{$\mathrm{C}-\mathrm{H}$ Bending } \\
\hline & $* * 923.20$ & & \\
\hline & $* * 854.06$ & & \\
\hline & $* * 694.52$ & & \\
\hline & $* * 669.35$ & & \\
\hline
\end{tabular}

Source: Authors

Table 4 shows the peak assignments in the infrared spectrum of the Film with $1.0 \mathrm{~mL}$ $\mathrm{CNF}$ loading. It shows the functional groups present in the films.

Figure 2. SEM Imaging of the Film with 0.0mL CNF Loading,

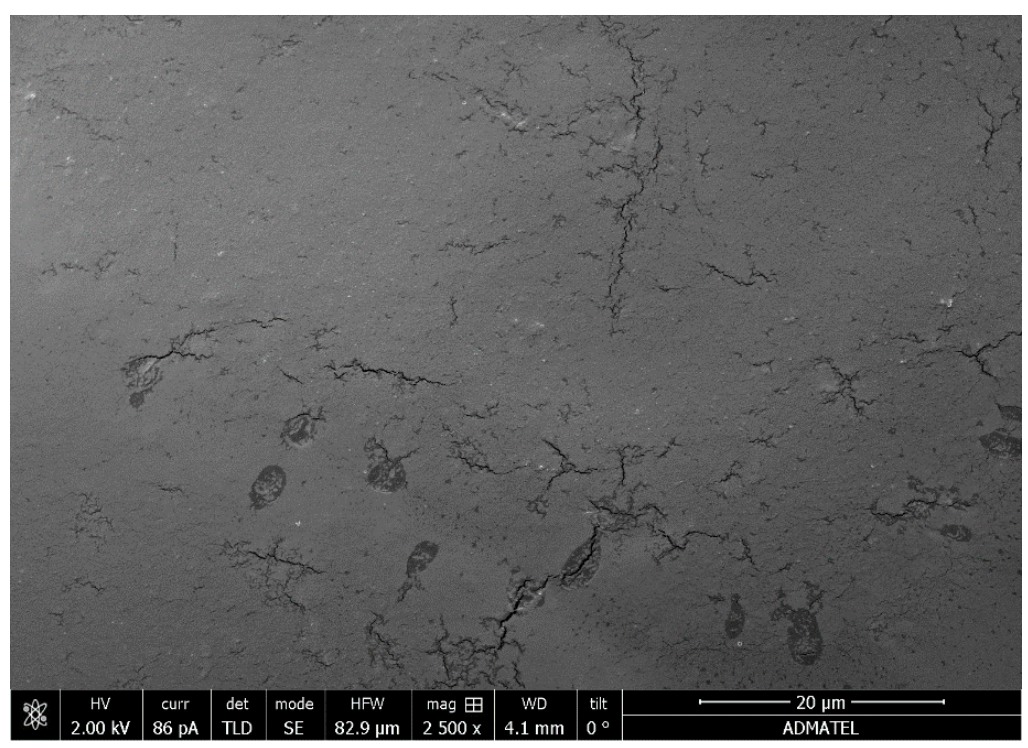

2500x Magnification

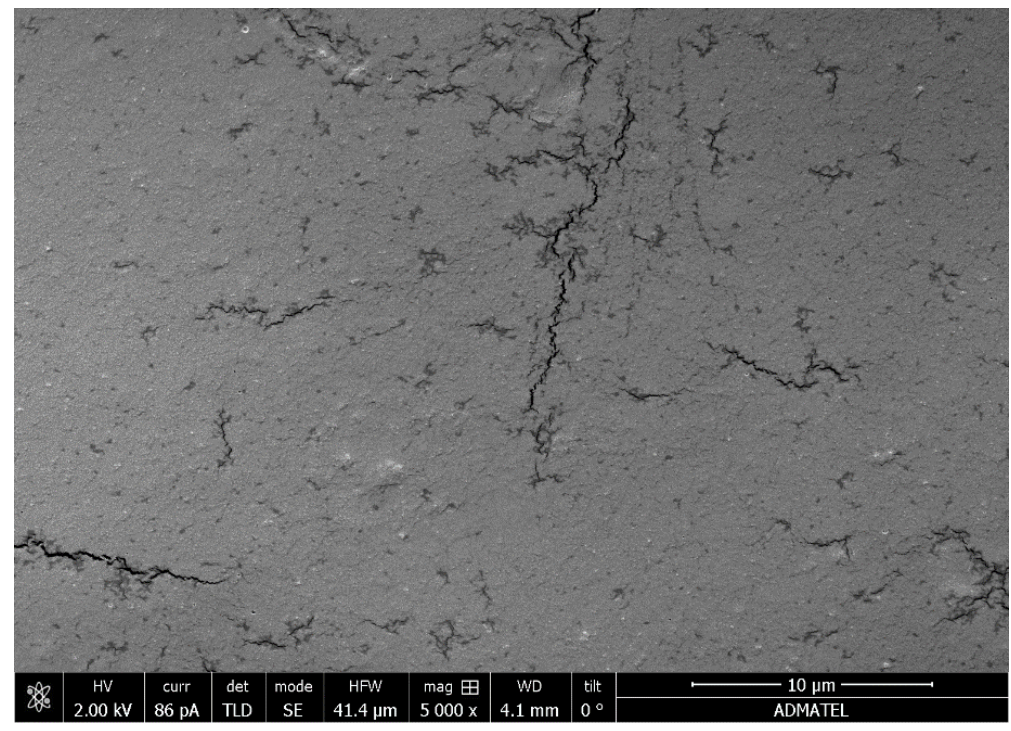

ISSN: 2709-0159(Print)

Copyright (c) 2020, Journal of Scientific Research in Medical and Biological Sciences (JSRMBS), Under the license CC BY- 4.0 


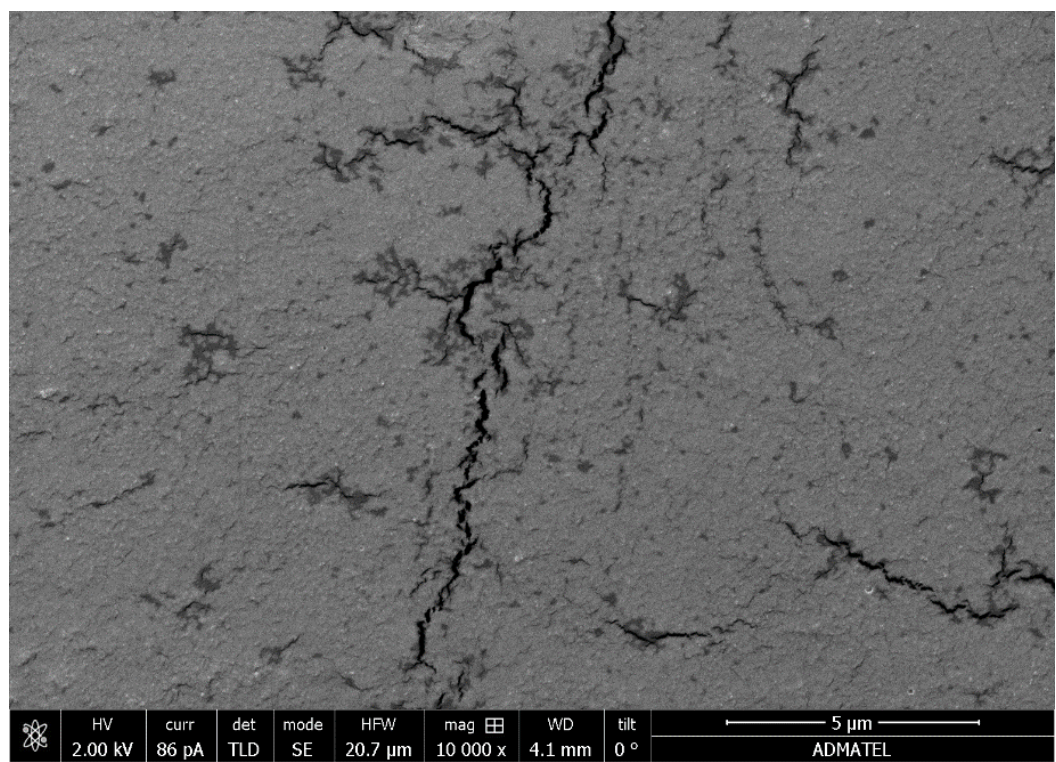

10000x Magnification

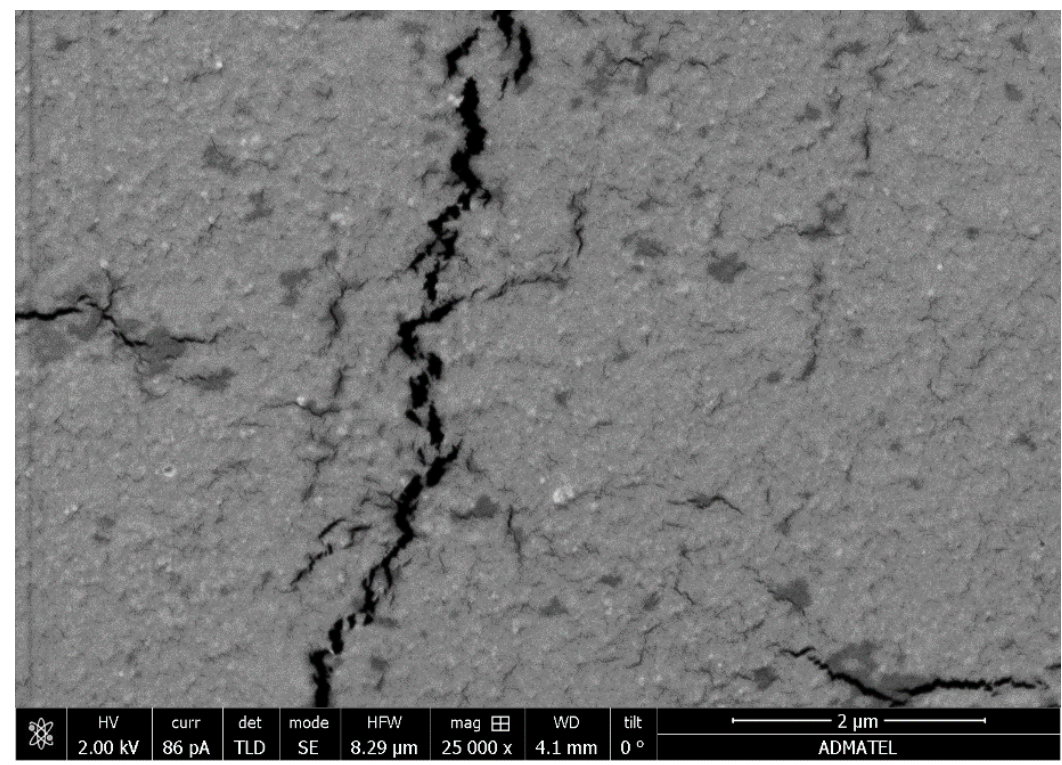

25000x Magnification

Figure 2 shows the morphology of the films with $0.0 \mathrm{~mL}$ Loading at 2500x, 5000x, 10000x and 25000x magnification.

Figure 3. SEM Imaging of the Film with 1.0mL CNF Loading 2500x Magnification the license CC BY- 4.0 


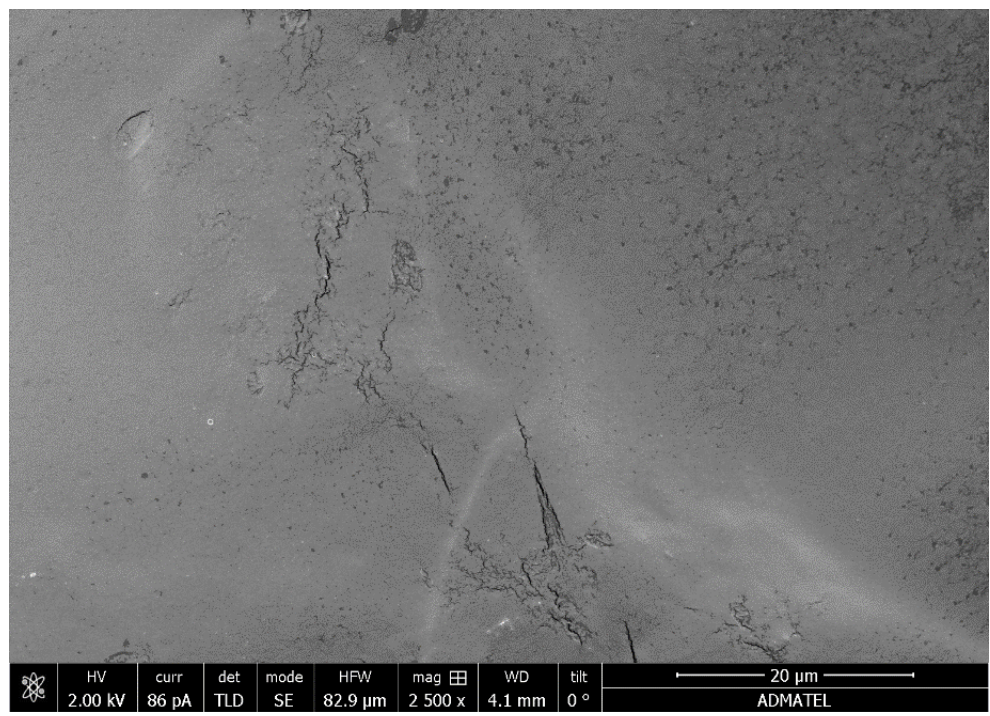

5000x Magnification

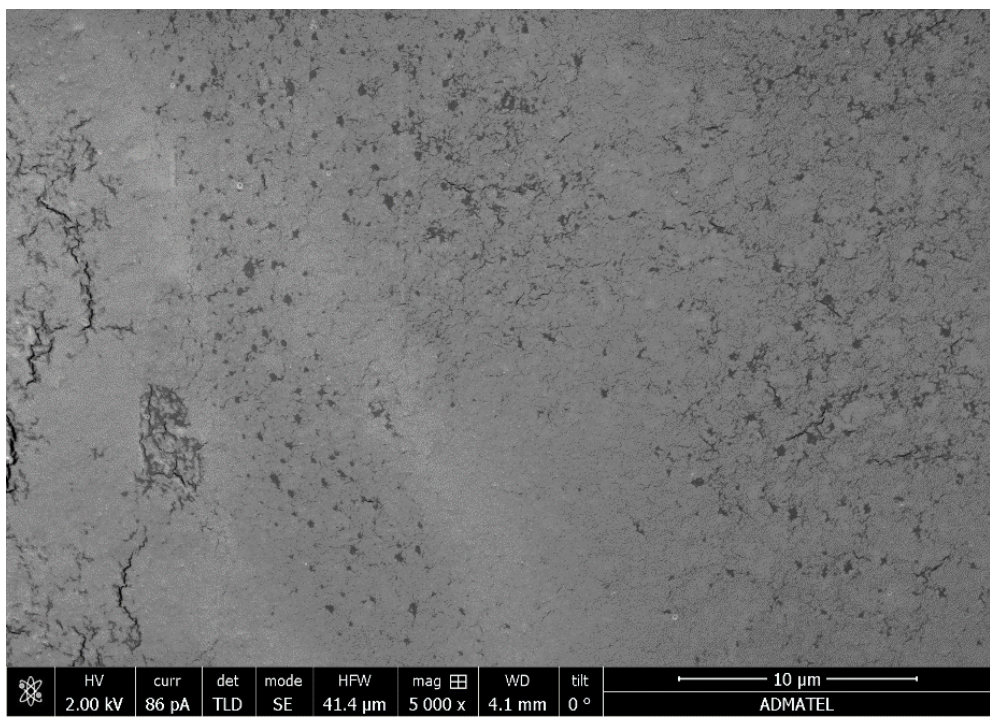

10000x Magnification the license CC BY- 4.0 


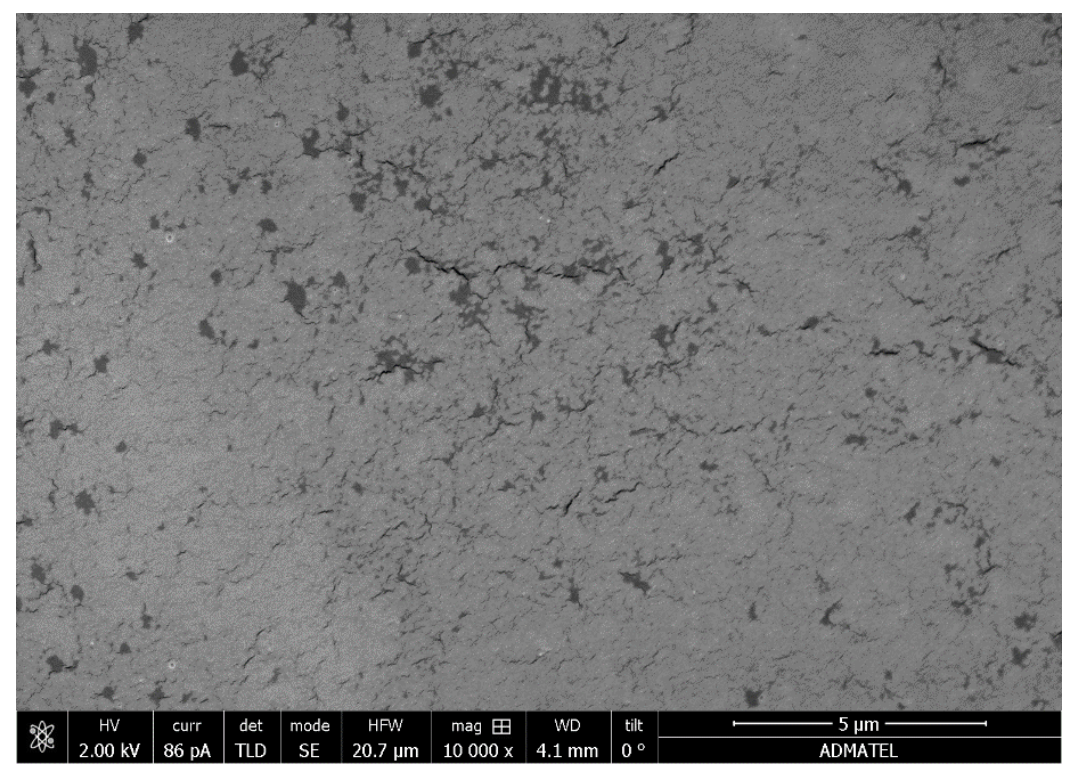

25000x Magnification

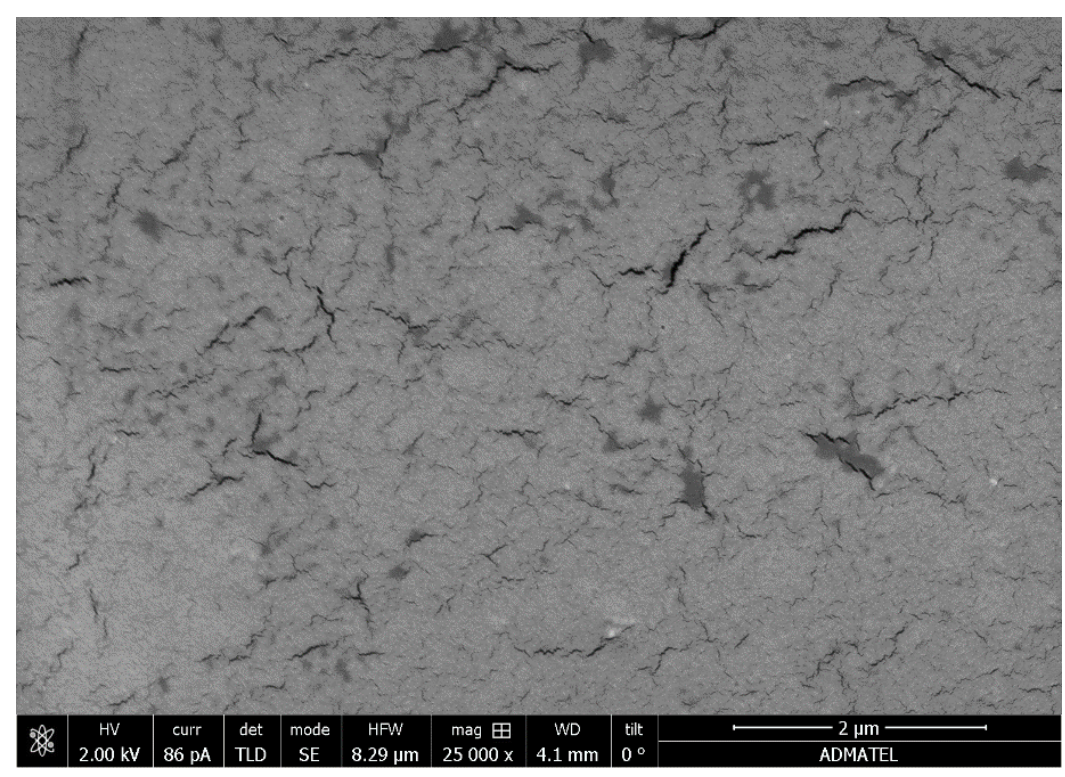

Figure 3 shows the morphology of the films with 1.0mL Loading at 2500x, 5000x, 10000x and 25000x magnification.

Table 5: Tensile Test of the Films

\begin{tabular}{|l|l|l|l|}
\hline \multicolumn{1}{|c|}{ Film } & \multicolumn{1}{|c|}{$\begin{array}{c}\text { Maximum Tensile } \\
\text { Stress(N) }\end{array}$} & $\begin{array}{c}\text { Maximum Expansion } \\
(\mathbf{m})\end{array}$ & $\begin{array}{c}\text { Maximum } \\
\text { Tensile Strength } \\
\left(\mathbf{N} / \mathbf{m}^{\wedge} \mathbf{2}\right)\end{array}$ \\
\hline $\begin{array}{l}\text { Film with 0.0mL CNF } \\
\text { Loading }\end{array}$ & 2 & 0.04 & 1250 \\
\hline $\begin{array}{l}\text { Film with 0.5mL CNF } \\
\text { Loading }\end{array}$ & 4.5 & 0.05 & 1600 \\
\hline $\begin{array}{l}\text { Film with 1.0mL CNF } \\
\text { Loading }\end{array}$ & 6 & 0.6 & 1666.67 \\
\hline
\end{tabular}

Source: Authors

ISSN: 2709-0159(Print)

Copyright (C) 2020, Journal of Scientific Research in Medical and Biological Sciences (JSRMBS), Under the license CC BY- 4.0 
Table 5: shows the Maximum Tensile Stress of the Films in Newton, Maximum Expansion of the Films in Meter And Maximum Tensile Strength obtained by N/m^2.

Table 6: Change in Length of Films

\begin{tabular}{|c|c|c|c|}
\hline \multirow{2}{*}{ Film } & \multicolumn{3}{|c|}{ Change in Length(mm) } \\
\cline { 2 - 4 } & 1 minute & 2 minutes & 3 minutes \\
\hline $\begin{array}{c}\text { Film with 0.0mL } \\
\text { CNF Loading }\end{array}$ & 0 & 0 & 0.20 \\
\hline $\begin{array}{c}\text { Film with 0.5mL } \\
\text { CNF Loading }\end{array}$ & 0 & 0 & .05 \\
\hline $\begin{array}{c}\text { Film with } 1.0 \mathrm{~mL} \\
\text { CNF Loading }\end{array}$ & 0 & 0 & 0 \\
\hline
\end{tabular}

Source: Authors

Table 6 shows the changes in length of films after being subjected to $80^{\circ} \mathrm{C}$ with $200 \mathrm{~g}$ load for 1 minute, 2 minutes and 3 minutes. It shows that there is no tremendous change with the length of the films.

Table 7: Dimensional Stability to Heat

\begin{tabular}{|l|c|c|c|}
\hline \multirow{2}{*}{ Film } & \multicolumn{3}{|c|}{ Dimensional Stability to Heat [(I/F)100] } \\
\cline { 2 - 4 } & 1 minute & 2 minutes & 3 minutes \\
\hline $\begin{array}{l}\text { Film with 0.0mL } \\
\text { CNF Loading }\end{array}$ & $100 \%$ & $100 \%$ & $96.22 \%$ \\
\hline $\begin{array}{l}\text { Film with 0.5mL } \\
\text { CNF Loading }\end{array}$ & $100 \%$ & $100 \%$ & $99.03 \%$ \\
\hline $\begin{array}{l}\text { Film with 1.0mL } \\
\text { CNF Loading }\end{array}$ & $100 \%$ & $100 \%$ & $100 \%$ \\
\hline
\end{tabular}

Source: Authors

Table 6 shows the dimensional stability of films after being subjected to $80^{\circ} \mathrm{C}$ with $200 \mathrm{~g}$ load for 1 minute, 2 minutes and 3 minutes. The film with 1.0mL CNF Loading stable until 3 minutes of being subjected to heat, while the films with $0.0 \mathrm{~mL}$ and $0.5 \mathrm{~mL} \mathrm{CNF} \mathrm{Loading}$ became unstable after 3 minutes of heating.

Figure 4. Stability in Alkaline Condition of Films

A. Film with 0.0mL CNF Loading
After 5 minutes
After 5 days 

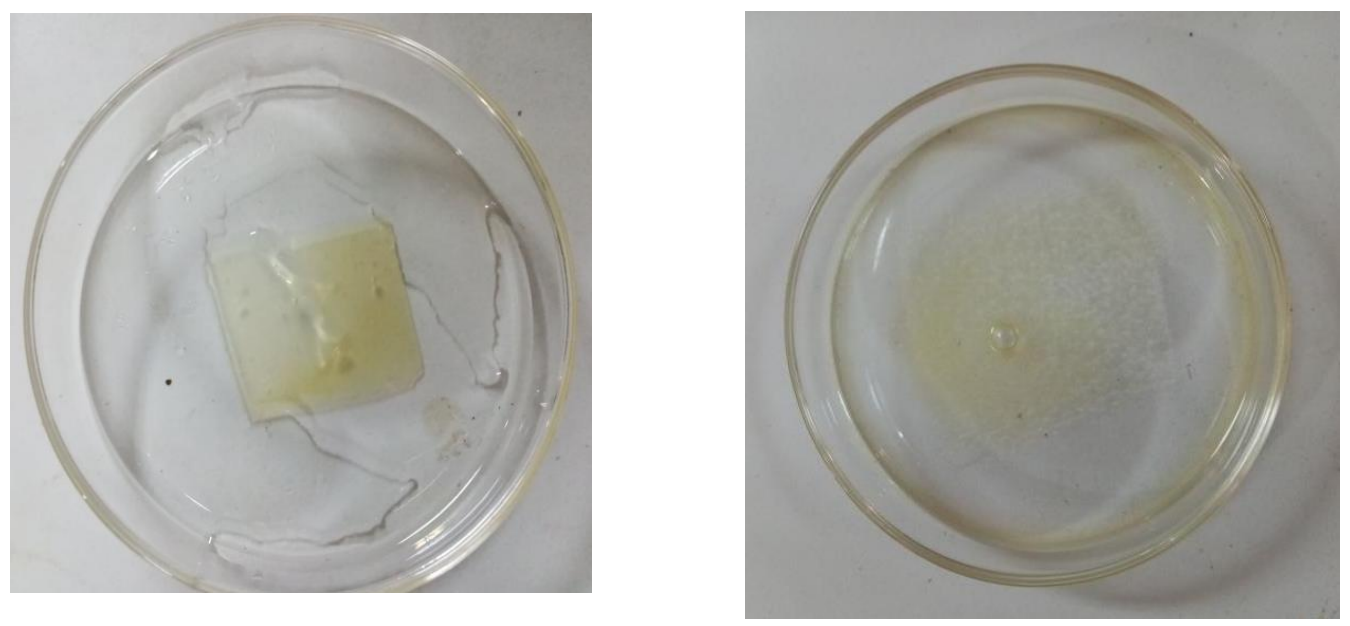

B. Film with $0.5 \mathrm{~mL}$ CNF Loading

After 5 minutes

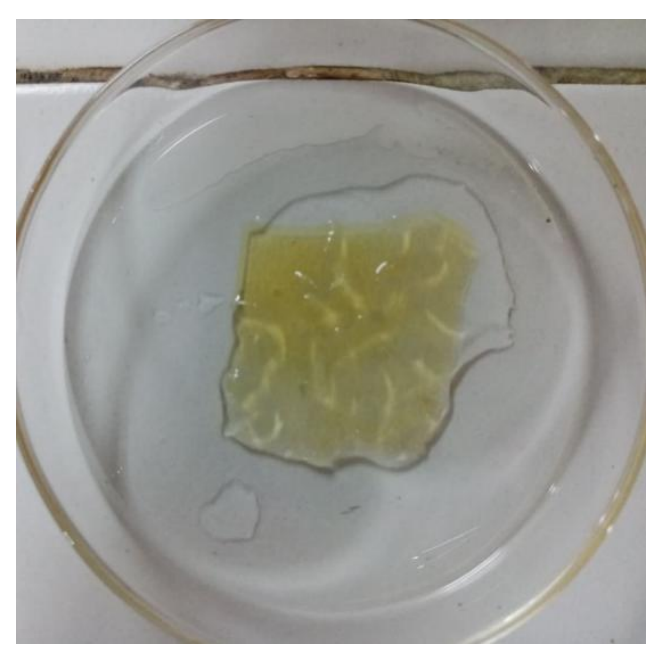

After 5 days

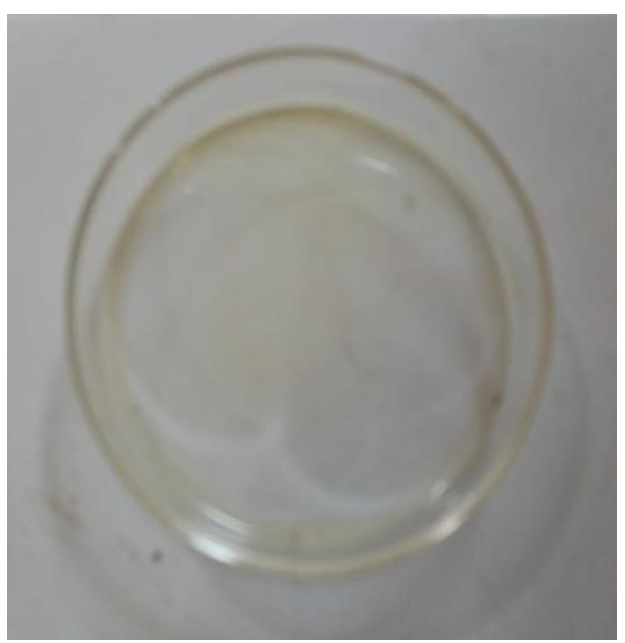

C. Film with 1.0mL CNF Loading the license CC BY- 4.0 
After 5 minutes

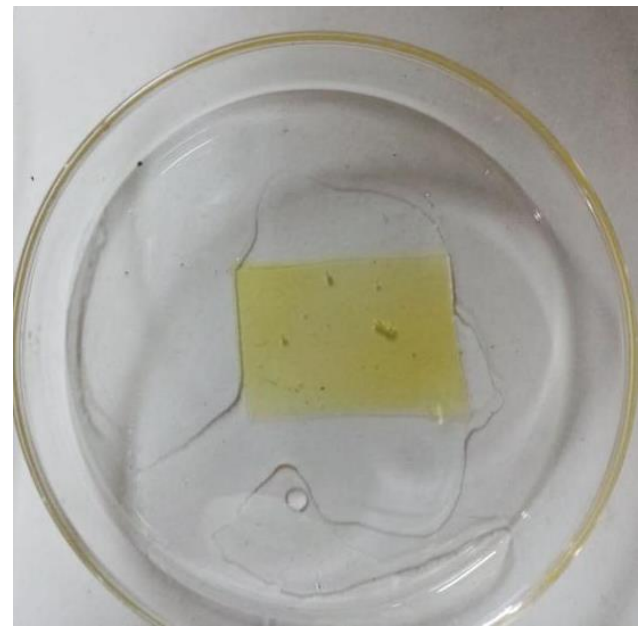

After 5 days

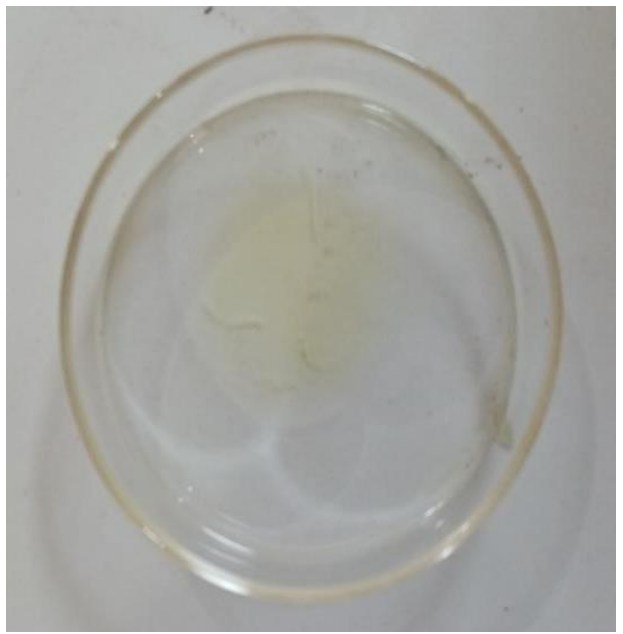

Figure 4 shows the disintegration of Films after being immersed in $0.1 \mathrm{M} \mathrm{NaOH}$ for 5 days, it displayed that the Films, disregard of CNF Loading, are unstable at alkaline conditions.

Figure 5. Stability in Acidic Condition of Films

A. Film with 0.0mL CNF Loading

After 5 minutes

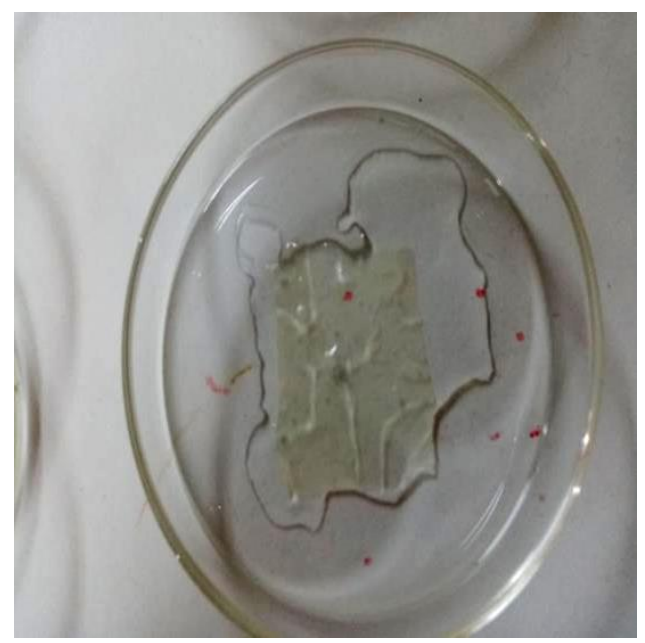

After 5 days

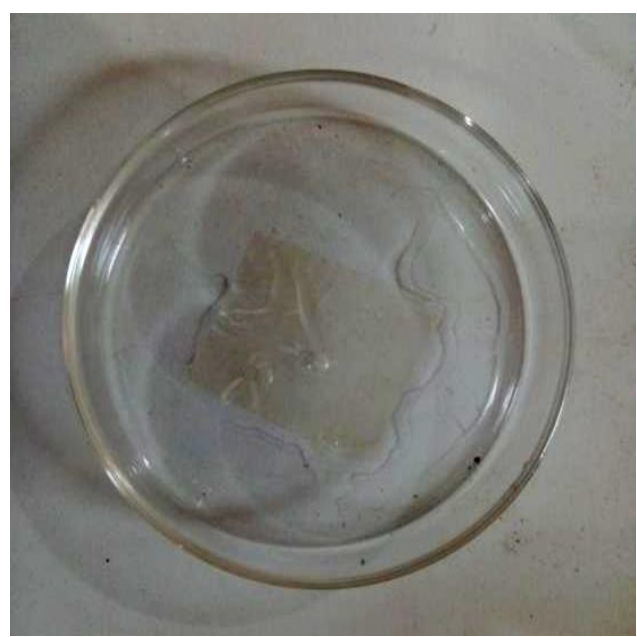




\section{B. Film with $0.5 \mathrm{~mL}$ CNF Loading}

After 5 minutes

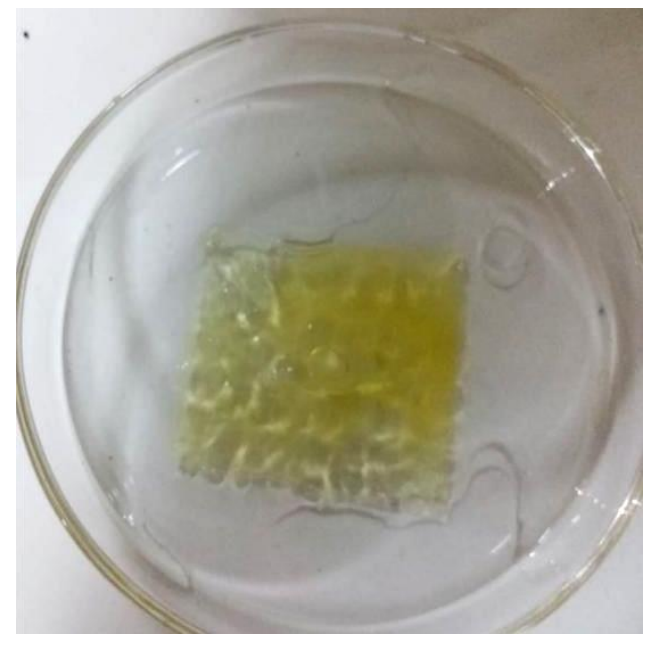

After 5 days

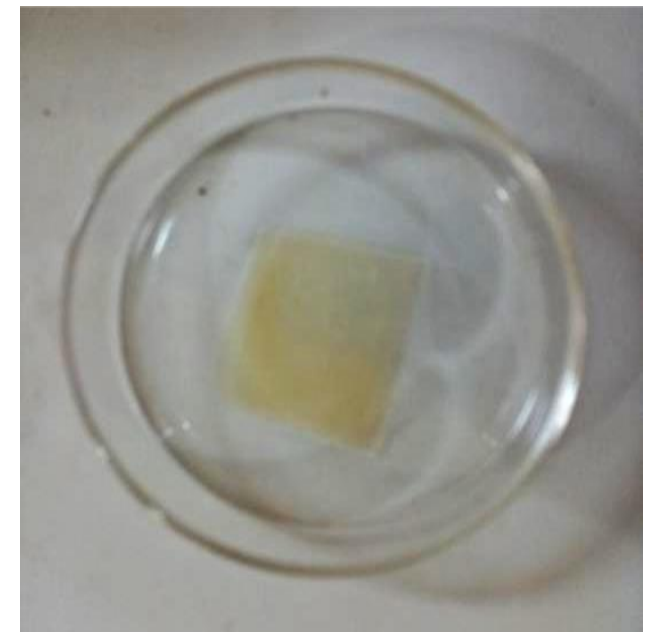

\section{Film with 1.0mL CNF Loading}

After 5 minutes

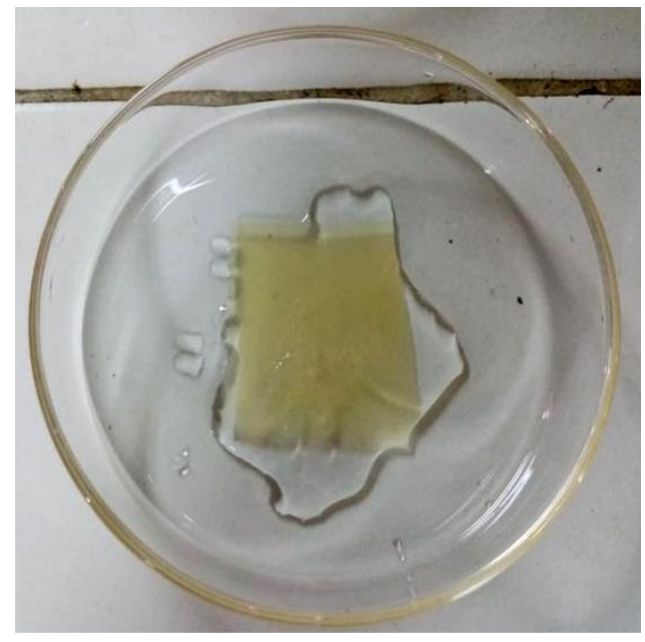

After 5 days

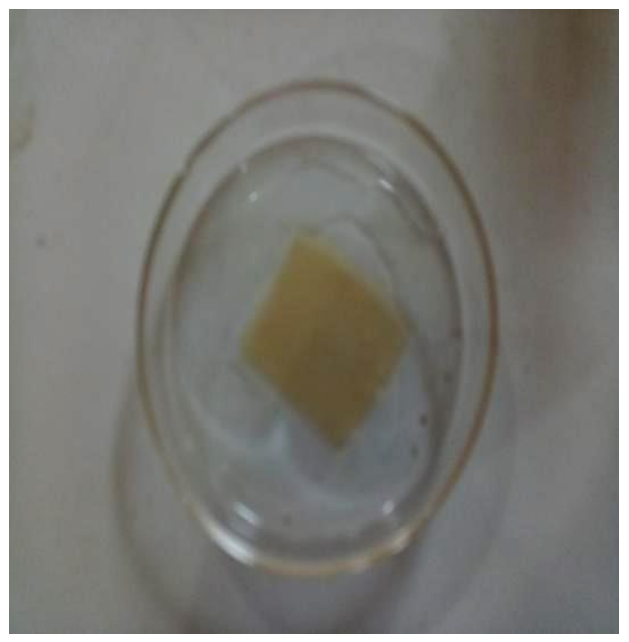

Figure 6 shows the minimal discoloration and disintegration of Films after being immersed in 0.1M HCL for 5 days, it displayed that the Films, disregard of CNF Loading, are stable at acidic conditions. 
Figure 6. Biodegradability Test

Film with $0.0 \mathrm{~mL}$ CNF Loading

After 4 Days

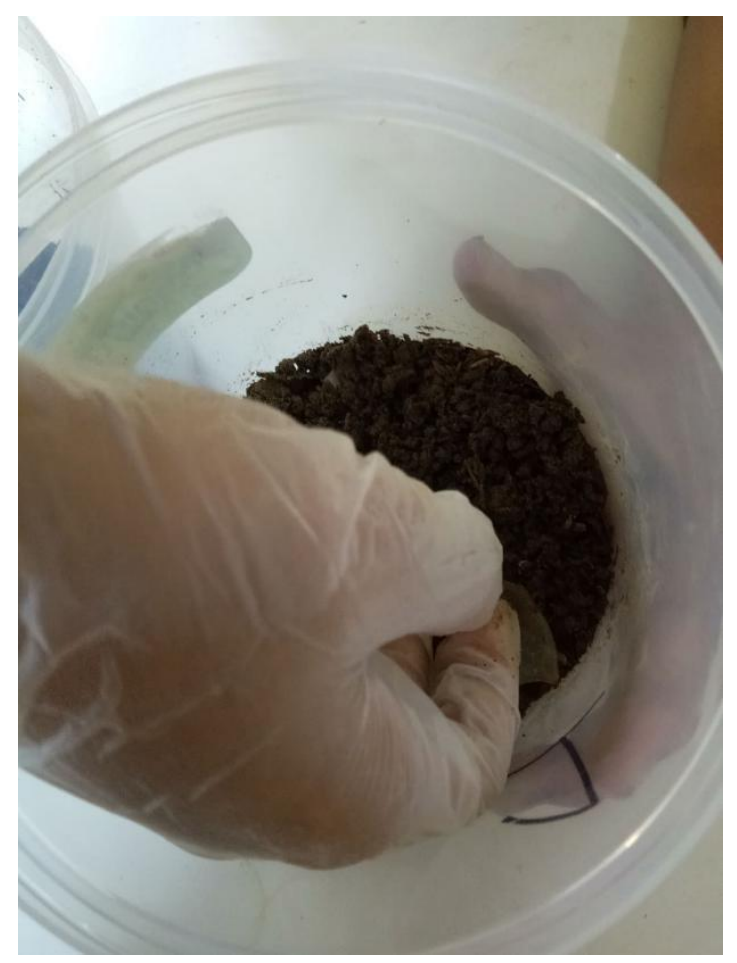

After 8 Days

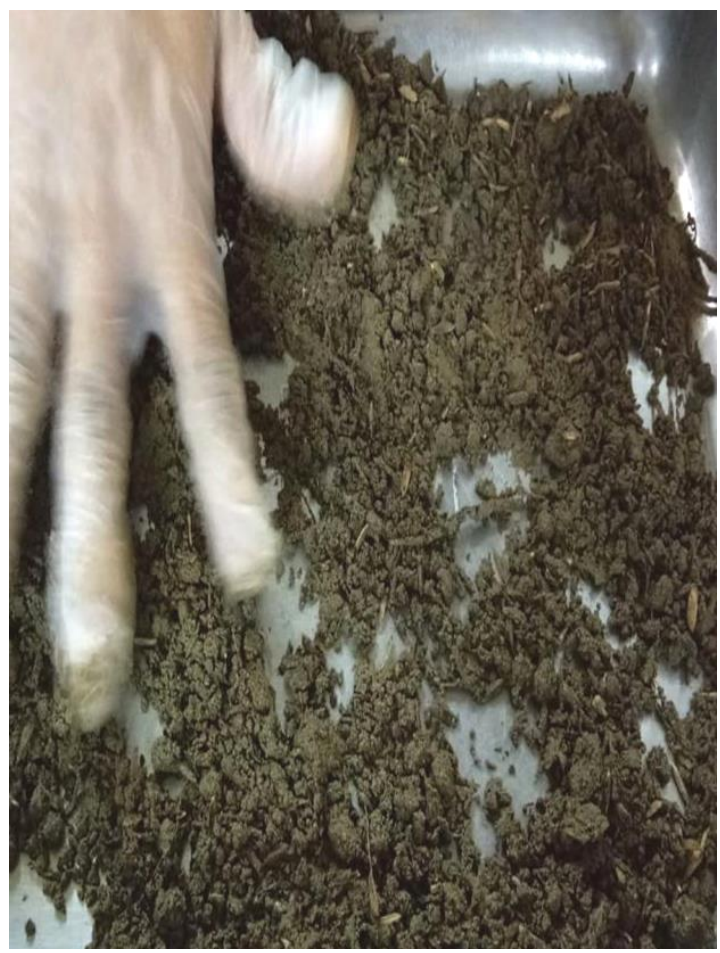

Film with $0.5 \mathrm{~mL}$ CNF Loading

After 4 Days

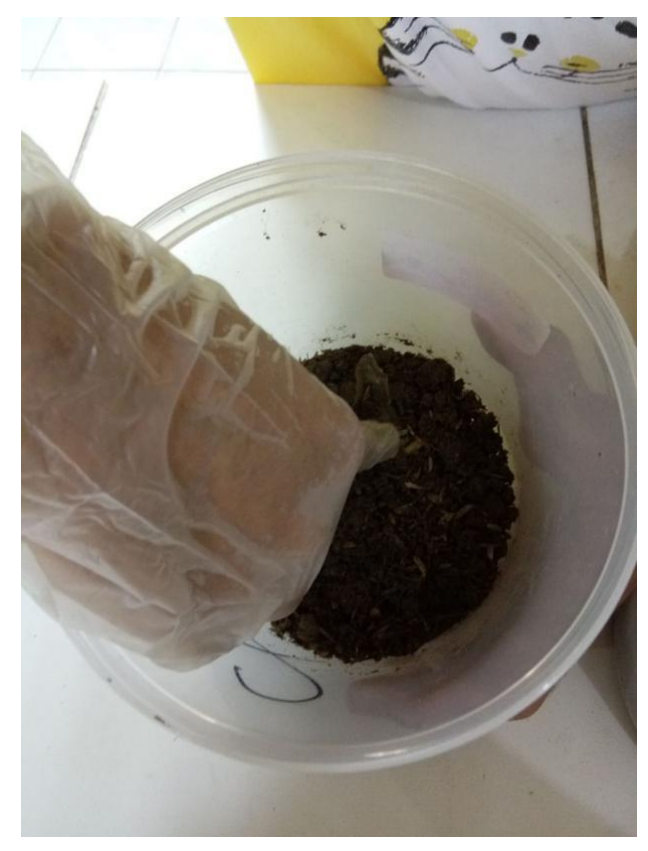

After 8 Days

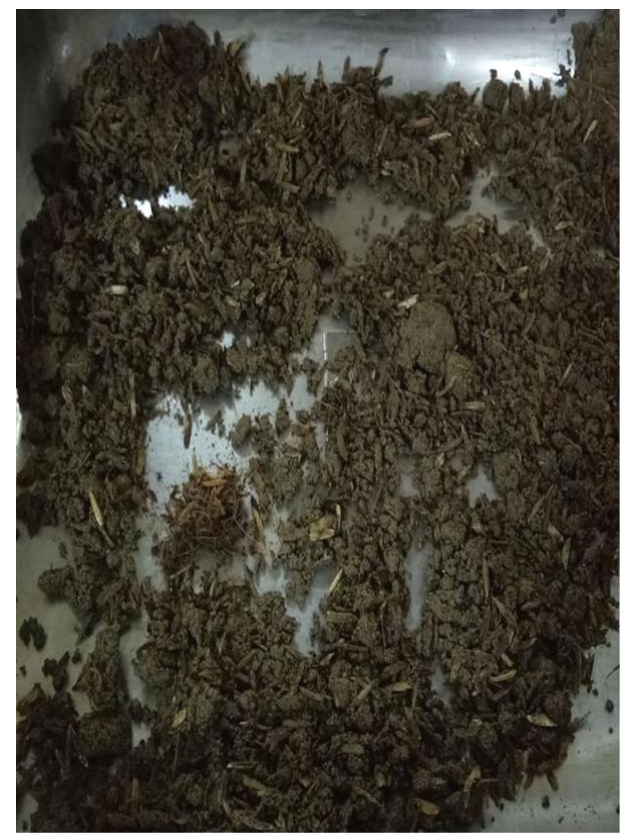


After 4 Days

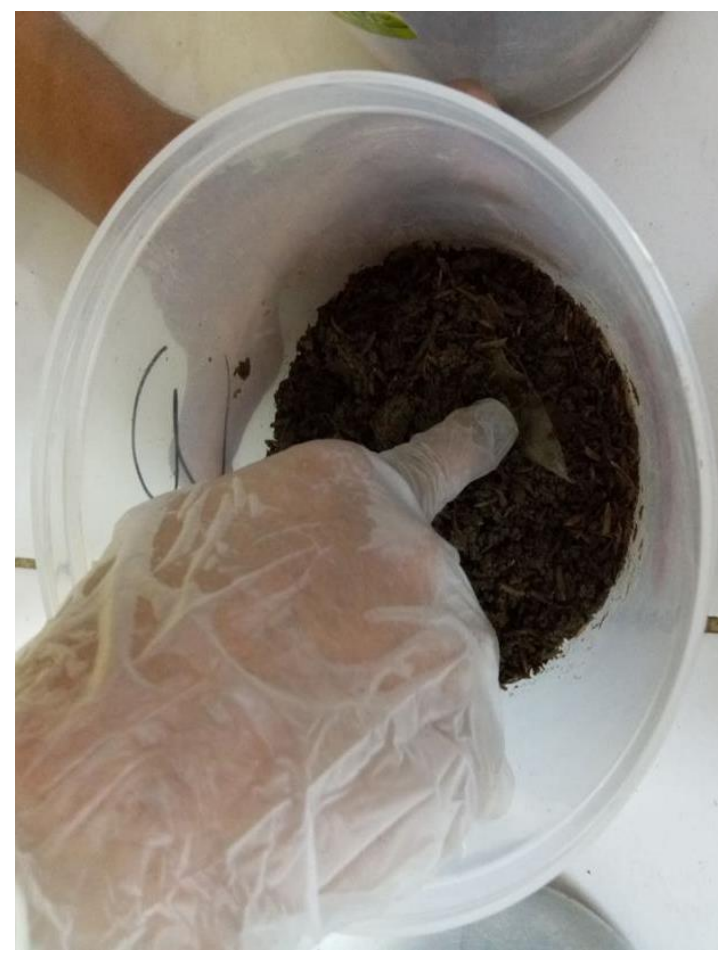

After 8 Days

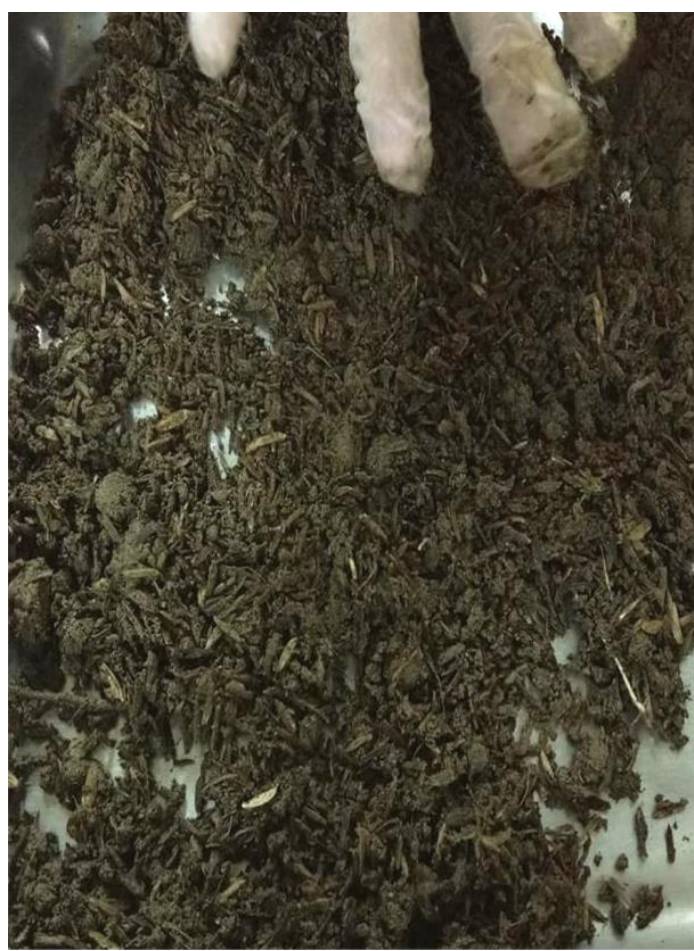

Figure 7 shows the biodegradation of the Films using soil as medium after 4 days and 8 days. The films degraded completely after 8 days. For all scans of SEM, the Scanning Electron Microscope used at any magnification was not able to trace the required nanofibers due to its opacity according to DOST-Admatel. However, the procedure used in the study is adapted from the study of $\mathrm{H}$. Tibolla et al. (2018), wherein CNF's obtained by Chemical Treatment had diameters of $10.9 \mathrm{~nm}$. The infrared vibration spectrum of the Film with $1 \mathrm{~mL}$ loading of CNF sample suggests the presence of Proteins. The compound was determined by identifying the characteristic frequencies as absorption bands in the infrared spectrum of the sample and compared with the characteristic group frequencies of reference compound. The results revealed by the mechanical tests: Tensile Strength Test, Stability in Acid and Basic Condition Test and Dimensional Stability Test, are in line with the results of the studies conducted by Boufi et al. (2014) and De Azeredo (2009). Consequently, the aspect ratio of nanofibers added to the polymer composites affects its mechanical properties significantly. The results of the biodegradability test showed significant proximity to what is stated in the study of Koshy, Rekha Rose (2015). Soy protein films was easily degraded in the soil disregard of the reinforcement of CNF and thus made the blends biodegradable as a whole.

\section{Conclusion and Suggestion}


Due to the given results of the tests conducted to the films, it is concluded that the addition of Banana Peel CNFs as retrofitting material to the Soy Protein Films materially strengthen the mechanical properties of the films and make them more suitable for food packaging applications. However, the aspect ratio of the CNF added to the films does not have any notable effect on the biodegradability of the films.

The study can be improved in many ways such as increasing the aspect ratios of CNFs per film. Ultrasonication can also be done to ensure the pureness of the CNF obtained. Furthermore, other tests like stability in Low and High Temperature can be done to strengthen the claim that the films can be truly used for food packaging. Cytotoxicity and genotoxicity evaluation can be added to support the findings that films can be used for packaging and is edible. For further research studies, the researchers also recommend the use of enzymatic treatment in isolating and extracting the required nanofibers from the plant material.

\section{Conflict of Interest}

The authors of the article declare no conflict of interest.

\section{Funding}

The authors received no funds for carrying out this research study.

\section{References}

Boufi, S., Kaddami, H., \& Dufresne, A. (2014). Mechanical performance and transparency of nanocellulose reinforced polymer nanocomposites. Macromolecular Materials and Engineering, 299(5), 560-568.

Cho, M. J., \& Park, B. D. (2011). Tensile and thermal properties of nanocellulose-reinforced poly (vinyl alcohol) nanocomposites. Journal of Industrial and Engineering Chemistry, 17(1), 36-40.

De Azeredo, H. M. (2009). Nanocomposites for food packaging applications. Food research international, 42(9), 1240-1253.

De Morais Teixeira, E., Bondancia, T. J., Teodoro, K. B. R., Corrêa, A. C., Marconcini, J. M., \& Mattoso, L. H. C. (2011). Sugarcane bagasse whiskers: extraction and characterizations. Industrial Crops and Products, 33(1), 63-66.

Dufresne, A. (2013). Nanocellulose: a new ageless bionanomaterial. Materials today, 16(6), 220-227.

Elanthikkal, S., Gopalakrishnapanicker, U., Varghese, S., \& Guthrie, J. T. (2010). Cellulose microfibres produced from banana plant wastes: Isolation and characterization. Carbohydrate polymers, 80(3), 852-859.

ISSN: 2709-0159(Print)

Copyright (C) 2020, Journal of Scientific Research in Medical and Biological Sciences (JSRMBS), Under 
Guo, G., Zhang, C., Du, Z., Zou, W., Tian, H., Xiang, A., \& Li, H. (2015). Structure and property of biodegradable soy protein isolate/PBAT blends. Industrial Crops and Products, 74, 731-736.

Kargarzadeh, H., Mariano, M., Huang, J., Lin, N., Ahmad, I., Dufresne, A., \& Thomas, S. (2017). Recent developments on nanocellulose reinforced polymer nanocomposites: A review. Polymer, 132, 368-393.

Khan, A., Huq, T., Khan, R. A., Riedl, B., \& Lacroix, M. (2014). Nanocellulose-based composites and bioactive agents for food packaging. Critical reviews in food science and nutrition, 54(2), 163-174.

Klawonn, I., Lavik, G., Böning, P., Marchant, H., Dekaezemacker, J., Mohr, W., \& Ploug, H. (2015). Simple approach for the preparation of 15-15N2-enriched water for nitrogen fixation assessments: evaluation, application and recommendations. Frontiers in microbiology, 6, 769.

Kokoszka, S., Debeaufort, F., Hambleton, A., Lenart, A., \& Voilley, A. (2010). Protein and glycerol contents affect physico-chemical properties of soy protein isolate-based edible films. Innovative Food Science \& Emerging Technologies, 11(3), 503-510.

Koshy, R. R., Mary, S. K., Thomas, S., \& Pothan, L. A. (2015). Environment friendly green composites based on soy protein isolate-A review. Food Hydrocolloids, 50, 174192.

Labonete, G.(2015). Fabrication of Graphene Oxide reinforced Soy Protein Film for possible Food Packaging Application. ADMU Department of Chemistry .

Lee, K. Y., Aitomäki, Y., Berglund, L. A., Oksman, K., \& Bismarck, A. (2014). On the use of nanocellulose as reinforcement in polymer matrix composites. Composites Science and Technology, 105, 15-27.

Majeed, K., Jawaid, M., Hassan, A. A. B. A. A., Bakar, A. A., Khalil, H. A., Salema, A. A., \& Inuwa, I. (2013). Potential materials for food packaging from nanoclay/natural fibres filled hybrid composites. Materials \& Design, 46, 391-410.

Mecking, S. (2004). Nature or petrochemistry?-biologically degradable materials. Angewandte Chemie International Edition, 43(9), 1078-1085.

Morán, J. I., Alvarez, V. A., Cyras, V. P., \& Vázquez, A. (2008). Extraction of cellulose and preparation of nanocellulose from sisal fibers. Cellulose, 15(1), 149-159.

Petersson, L., Mathew, A. P., \& Oksman, K. (2009). Dispersion and properties of cellulose nanowhiskers and layered silicates in cellulose acetate butyrate nanocomposites. Journal of Applied Polymer Science, 112(4), 2001-2009.

Rhim, J. W., \& Perry. K. (2007). Natural biopolymer-based nanocomposite films for packaging applications. Critical reviews in food science and nutrition, 47(4), 411433.

Robertson, G. L. (2016). Food packaging: principles and practice. CRC press.

Rosario, L., \& Dell, E. (2010). Biodegradability of Plastics Testing in an Undergraduate Materials Laboratory. In American Society for Engineering Education. American Society for Engineering Education.

Sharma, S., \& Luzinov, I. (2013). Whey based binary bioplastics. Journal of Food Engineering, 119(3), 404-410.

ISSN: 2709-0159(Print)

Copyright (C 2020, Journal of Scientific Research in Medical and Biological Sciences (JSRMBS), Under the license CC BY- 4.0 
Tang, X. Z., Kumar, P., Alavi, S., \& Sandeep, K. P. (2012). Recent advances in biopolymers and biopolymer-based nanocomposites for food packaging materials. Critical reviews in food science and nutrition, 52(5), 426-442.

Tibolla, H., Pelissari, F. M., Martins, J. T., Vicente, A. A., \& Menegalli, F. C. (2018).

Cellulose nanofibers produced from banana peel by chemical and mechanical treatments: characterization and cytotoxicity assessment. Food Hydrocolloids, 75, 192201. 